\title{
Comparative study of impact of Azotobacter and Trichoderma with other fertilizers on maize growth
}

\author{
${ }^{1,2}$ Sanjay Mahato and ${ }^{2}$ Srijana Neupane \\ ${ }^{1}$ Aasra Research and Education Academic Counsel, Biratnagar - 7, Nepal, \\ ${ }^{2}$ Institute of Agriculture and Animal Science, Lamjung Campus, Nepal \\ *Corresponding author email: mahato.sanjay@gmail.com, \\ ORCID ID: https://orcid.org/0000-0002-0154-8129
}

Received: July 15, 2017; Revised: October 01, 2017; Accepted: November 05, 2017

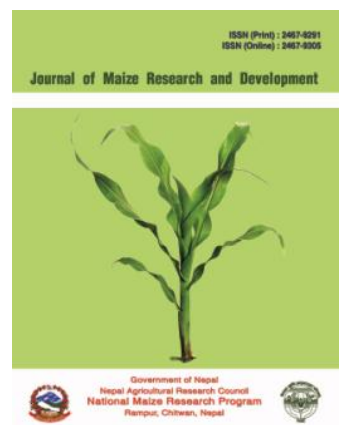

(C) Copyright 2017 Mahato and Neupane.

(c) (1) (9) This work is licensed under a Creative Commons Attribution-NonCommercial 4.0 International License.

\begin{abstract}
Biofertilizers may be a better eco-friendly option to maintain soil fertility. The study was conducted to investigate the effect of Azotobacter and Trichoderma on the vegetative growth of maize (Zea mays L.) plants. The experiment was carried out in medium sized pots, at IAAS, Lamjung (Feb 2017 - May 2017) in completely randomized design (CRD), consisting eight treatments and three replications. Treatments were namely T1 (control), T2 (Azotobacter), T3 (Trichoderma), T4 (Azotobacter + Trichoderma), T5 (NPK), T6 (Azotobacter + Trichoderma + FYM), T7 (Azotobacter + Trichoderma + FYM + NPK), T8 (FYM). Azotobacter showed a positive increase in plant height, stem girth, dry shoot weight, root length and width, and root weight while Trichoderma displayed either negative or minimal impact. Effect of FYM was lower than Azotobacter but considerably higher than Trichoderma. Trichoderma seriously inhibited the expression of Azotobacter when used together. Trichoderma even suppressed the outcome (except shoot weight) of FYM when used together. Root length was the longest in Azotobacter inoculation. The highest number of leaves was in T7 followed by Azotobacter (T2) and NPK (T5). Unlike leaf width, Azotobacter showed a negligible increase in leaves length while Trichoderma wherever present showed the negative impact. Minimum chlorophyll content was found in Azotobacter or Trichoderma after 73 days. Azotobacter treatment showed early tasseling than Trichoderma. The association of Azotobacter and Trichoderma increased the biomass. Azotobacter has significant effects on growth parameters of maize and can supplement chemical fertilizer, while Trichoderma was found to inhibit most of the growth parameters.
\end{abstract}

Keywords: Azotobacter, Trichoderma, Maize, Farmyard manure, NPK

Correct citation: Mahato, S., \& Neupane, S. (2017). Comparative study of impact of Azotobacter and Trichoderma with other fertilizers on maize growth. Journal of Maize Research and Development, 3(1), 1-16. doi: http://dx.doi.org/10.3126/jmrd.v3i1.18915. 
Journal of Maize Research and Development (2017) 3 (1):1-16

ISSN: 2467-9291 (Print), 2467-9305 (Online),

DOI: http://dx.doi.org/10.3126/jmrd.v3i1.18915

\section{INTRODUCTION}

Maize (Zea mays) is second most important crop after rice in terms of area and production in Nepal. In the context of Nepal, the importance of maize increase with altitude, eventually standing as a staple crop in northern part of the country (KC et al., 2015). In the context of world, 58\% of maize is utilized in animal feed, $16 \%$ in human food and $26 \%$ in bioethanol production (HLPE, 2013), whereas, study shows that 60\%, 25\% and 3\% of grain were used for animal feed, food and seed respectively in the hilly district of Nepal and rest is sold to the traders (Timsina et al., 2016). Mainly, organic manure (FYM), urea, green manure and recently some kinds of biofertilizer are being used as the source of nitrogen in Nepal. Application of nitrogen and phosphate biofertilizers in maize results in significant increase in plant height, root and shoot weight, ear weight, number of grain per cob, and grain yield (Beyranvand et al., 2013). Addition of both nitrogen and phosphorus fertilizers is necessary to attain the maximum yield (Farnia \& Ashjardi, 2015).

Azotobacter, an aerobic free-living soil microbe widely used as biofertilizer, binds atmospheric nitrogen and release it in the form of ammonium ions into the soils. They are ubiquitous and abundantly found in neutral to weakly acidic soils. In dry soils, Azotobacter can survive in the form of cysts for up to 24 years (Moreno et al., 1986). Nitrogen application base on soil test and in inoculation of soil with $2 \mathrm{~kg} / \mathrm{ha}$ bacteria produced the highest number of grains per row, the total number of grains per corn, the weight to 1000-grain, harvest index is produced that make increase of seed/grain yield (Amiri \& Rafiee, 2013). Nitragin (Azotobacter, Azospirillum, Pseudomonas) inoculation seeds have $44 \%$ higher LAI and 61\% higher leaf chlorophyll index and $24 \%$ increase in ear dry weight (Kouchebagh et al., 2012).Regardless of organic matter application, inoculation of corn with Azotobacter resulted in an increase of 78.7\% in dry matter yield when compared with application of urea only (Soliman \& Abel Momen, 1994). Azotobacter enhanced biofertilizer has the significant increase in plant growth and yield of maize (Wani et al., 2016). Highest yield may be due to maximum leaf area, highest weight of leaf and highest chlorophyll content. Also, highest biomass and greatest harvest index were recorded over other treatments.Inoculation of seeds with Azotobacter and Azospirillum produced more yield compared to fertilizer application alone (Laxminarayana, 2001).

Trichoderma refers to the genus of fungi, which mostly have a mutualistic relationship with plants. It consists of many species, about 100 identified by molecular data till now (Druzhinina, Kopchinskiy, \& Kubicek, 2006). These are typically fast growing at $25^{\circ}-30^{\circ} \mathrm{C}$ but can grow well up to $45^{\circ} \mathrm{C}$. Several strains of Trichoderma have been used as biocontrol agent due to several mechanisms like antibiosis, parasitism, host-plant resistance and competition which has now been popular as biofertilizer and biopesticide together (Kaewchai et al., 2009). Trichoderma enriched biofertilizers are being used due to their recognized roles in growth, yield and nutritional quality of various crops including- maize, bean, cucumber, and tomato (Yedidia et al., 1999; Hoyos-Carvajal et al., 2009; Molla et al., 2012; Saravanakumar et al., 2017). Trichoderma, being a fungus, affects positively or negatively to higher plants. Kleifeld \& Chet (1992) and Harman et al (2004) reported stimulating effects of Trichoderma on maize growth whereas there are many others reporting negative growth as well (Kohl \& Schlösser, 1989). Pathogenic isolates of Trichoderma spp on maize were reported by McFadden and Sutton (1975). 
Journal of Maize Research and Development (2017) 3 (1):1-16

ISSN: 2467-9291 (Print), 2467-9305 (Online),

DOI: http://dx.doi.org/10.3126/jmrd.v3i1.18915

The application of $T$. harzianum on maize increases all measured parameters which include growth parameters, chlorophyll content, starch content, nucleic acids content, total protein content and phytohormones content of maize plants, when applied to the soil or the seeds but the magnitude of the increase was much more pronounced in case of plants developed from seeds treated with various concentrations of metabolic solution of T. harzianum (Akladious \& Abbas, 2012). Iranian Trichoderma on seed germination show reduced the speed of seed germination on maize (Hajieghrari, 2010). However, only limited information is available on effects of antagonistic fungi on higher plants. The exact physiology of Trichoderma as a biofertilizer is yet to be studied.

\section{MATERIALS AND METHODS}

\section{Experimental Site}

The research was carried out in the location of Sundarbazzar, Lamjung, western hills of Nepal during the spring season (February 2017 - June 2017). The site is located at an elevation of 610 masl with the latitude of $28^{\circ} 8^{\prime} 41^{\prime \prime} \mathrm{N}$ and longitude of $84^{\circ} 24^{\prime} 43^{\prime \prime} \mathrm{E}$.

\section{Soil Analysis}

The $\mathrm{pH}$, organic matter, nitrogen, phosphorus, and potash content of the soil sample were analyzed.

\section{Design of Experiment}

The experiment was carried out in the pot with eight treatments and three replications following Completely Randomized Design (CRD). There were 24 pots in total, each having single maize plant. To maintain suitable moisture condition in the pot, the hole was drilled into the pot. For pot filling, the soil was collected from the horticultural farm of IAAS, Sundarbazaar, Lamjung Nepal. Nearly $2.5 \mathrm{~kg}$ of thoroughly mixed soil was filled into the pot $(15 \mathrm{~cm}$ in diameter and 15 $\mathrm{cm}$ in height). Two maize seeds of Arun-2 variety were, then, placed in each pot for germination insurance. Maize seeds were collected from a commercial seed trader of Sundarbazaar, Lamjung, Nepal. Seed inoculation for Azotobacter and soil inoculation technique for Trichoderma viride was used.

The treatments were control (T1), Azotobacter seed coated (T2), Trichoderma soil inoculated (T3), Azotobacter seed coated + Trichodermasoil inoculated (T4), only inorganic fertilizer 120:40:40 NPK kg ha ${ }^{-1}$ (T5), Azotobacter seed coated + Trichoderma soil inoculated + 10 t FYM $\mathrm{ha}^{-1}$ (T6), Azotobacter seed coated + Trichoderma soil inoculated + 10 t FYM ha ${ }^{-1}+120: 40: 40$ NPK kg ha ${ }^{-1}$ (T7) and only FYM (T8). For control, neither manure and nor fertilizer was applied. Fertilizer sources were Azotobacter, Trichoderma, FYM and chemical fertilizer (Urea for Nitrogen). FYM was used from the IAAS Campus Farm at the rate of 10 ton/ha.

The amount of fertilizer, biofertilizer, and FYM for one plant was calculated using a formula for the estimation of plant population per hectare $(\mathrm{Pp})$. The total amount of fertilizer, biofertilizer, and FYM required for one hectare was divided by plant population per hectare. Thus, the need for amount per plant was obtained.

$$
P p=\frac{10,000 \mathrm{~m}^{2} \mathrm{X} \text { number of seeds per stand }}{{\text { Product spacing }\left(\mathrm{m}^{2}\right)} \text {. }}
$$


The product of spacing used was $75 \mathrm{~cm} \times 25 \mathrm{~cm}$ while the number of seed per stand was 1 . This resulted in plant population of 53,333 plants per hectare (Olaniyan et al., 2004; Okoroafor et al., 2013).

Fertilizer per plant $=\frac{\text { Amount of fertilizer per hectare }}{\text { Plant population per hectare }}$

187.5 gm of well-decomposed FYM (Farmyard manure) per pot was used as each plant. As inorganic fertilizer $120 \mathrm{~kg}$ of urea, $40 \mathrm{~kg}$ of MOP and $40 \mathrm{~kg}$ of DAP were used for nitrogen, phosphorous and potassium (NPK) source for a hectare.

Maize being a heavy feeder crop requires a huge amount of nutrients in comparison to other cereals. A normal dose of 120:40:40 kg NPK/ha for the nutrient supplement of the crop (Urea$4.25 \mathrm{~g}$, MOP-1.25 g, DAP-1.63 g per pot) was applied. Half urea was applied as basal dose and the half was top dressed.

\section{Trichoderma soil inoculation}

Azotobacter spp. was seed inoculated, in the dose guided by the label, $40 \mathrm{~g}$ for 0.25 ha. Per plant share was calculated and applied. Seed inoculation with Azotobacter was carried out by $10 \%$ sugar solution carrier. To inoculate Trichoderma viride, $0.02 \%$ solution was prepared and 150 $\mathrm{ml}$ of Trichoderma solution was used per pot, directly to the soil.

\section{Sowing, Irrigation, and Top Dressing}

Sowing and light irrigation were done on February 23, 2017. After the complete germination, the maize plants were thinned out leaving single maize plant in each pot. Irrigation with $250 \mathrm{ml}$ of water was done whenever necessary. Due to the small capacity of pots and very high temperature during critical stages, irrigating the pots daily was required in case of no rainfall day. The top dressing was essential due to the small size of pot and deficiency symptoms. It was done on 26 days after sowing. Dibbling was used as top dressing method.

\section{Weed control and Harvesting}

Hand weeding was done, whenever necessary. Minor aphid infestation was controlled by spraying detergent water $(0.005 \%)$ to maize plants for two weeks on alternate days. Harvesting was done manually on June 20, 2017 (113 days after sowing).

\section{Data Collection}

Days of germination, plant height, stem girth, leaf number, leaf length and width, SPAD reading, days to tasseling, root length and width, dry root and shoot weight, and total biomass were taken.

\section{Data Analysis}

MS-Excel version 13 was used to record the data and perform simple statistical analysis as well as table, charts, and graph. Further statistical analysis to determine the significance (at a level of 5\%) among various treatments was performed using Genstat version 15. 
Journal of Maize Research and Development (2017) 3 (1):1-16

ISSN: 2467-9291 (Print), 2467-9305 (Online), DOI: http://dx.doi.org/10.3126/jmrd.v3i1.18915

\section{RESULTS AND DISCUSSION}

The soil $\mathrm{pH}$ was found to be acidic 6.0 , organic matter $2.81 \%$ (medium), nitrogen $0.14 \%$ (medium), phosphorus $216.68 \mathrm{~kg} / \mathrm{ha}$ (high) and potash $534.9 \mathrm{~kg} / \mathrm{ha}$ (high). Trichoderma showed delayed germination (7.3 days) compared to Azotobacter (7 days) or control (7 days). Trichoderma when used with Azotobacter inhibited the response of Azotobacter and delayed the germination (7.3 days). NPK (T5), Azotobacter + Trichoderma + FYM (T6) and FYM (T8) showed faster germination (6.67 days). The fastest germination was observed in T7 (Azotobacter + Trichoderma + FYM + NPK) of 6.5 days. Though the speed of germination was different, but the rate of germination was same for all the treatments. Inhibition or delayed germination with Trichoderma is supported by Hajieghrari (2010), while Azotobacter expedites the germination as shown by Bákonyi et al (2013).

Out of all the eight treatment for maize plant, T7 (Azotobacter, Trichoderma, FYM and NPK) had the highest value for the parameters like plant height, dry shoot weight, stem girth, dry root weight, and root width with an increase of $37.7 \%, 269.5 \%, 58.2 \%, 793.8 \%$, and $67.8 \%$ respectively over control T1 (soil only). T7 was followed by T5 (NPK only) and T2 (Azotobacter only) successively in all above parameters like plant height, dry shoot weight, stem girth, dry root weight, and root width with an increase of $31.8 \%, 244.6 \%, 50 \%, 296.4 \%, 42.8 \%$ and $23.48 \%, 59.5 \%, 10 \%, 149.5 \%, 27.4 \%$.T8 (FYM only) followed T2 in terms of parameters like plant height, stem girth, dry root weight, and root width $18.8 \%, 9.3 \%, 41.0 \%, 10.4 \%$ respectively. Trichoderma (T3) showed a negative impact on the plant height and stem girth with a decrease of $8.6 \%$ and $3.2 \%$ over control. Trichoderma showed the negligible increase of $4.9 \%$, $8.8 \%$ and $2.2 \%$ in dry shoot weight, root weight, and root width respectively.

Table 1: Effects of different treatments on different parameters of maize in Lamjung

\begin{tabular}{|c|c|c|c|c|c|}
\hline Treatment & $\begin{array}{l}\text { Plant height } \\
\text { (cm) }\end{array}$ & Stem girth $(\mathrm{cm})$ & $\begin{array}{l}\text { Root length } \\
\text { (cm) }\end{array}$ & $\begin{array}{l}\text { Root Width } \\
\text { (cm) }\end{array}$ & $\begin{array}{l}\text { Dry root } \\
\text { weight }(\mathrm{g})\end{array}$ \\
\hline $\mathrm{T} 1$ & $126.2^{\mathrm{b}} \pm 1.42$ & $2.803^{\mathrm{a}} \pm 0.04$ & $39.4^{\mathrm{c}} \pm 0.52$ & $4.53^{\mathrm{a}} \pm 0.15$ & $10.73^{\mathrm{a}} \pm 0.7$ \\
\hline $\mathrm{T} 2$ & $155.8^{\mathrm{e}} \pm 3.97$ & $3.078^{\mathrm{a}} \pm 0.12$ & $44.1^{\mathrm{cd}} \pm 1.01$ & $5.77^{\mathrm{b}} \pm 0.26$ & $26.77^{\mathrm{b}} \pm 1.94$ \\
\hline $\mathrm{T} 3$ & $115.3^{\mathrm{a}} \pm 1.2$ & $2.711^{\mathrm{a}} \pm 0.09$ & $44.7^{\mathrm{e}} \pm 0.67$ & $4.63^{\mathrm{a}} \pm 0.22$ & $11.67^{\mathrm{a}} \pm 0.92$ \\
\hline $\mathrm{T} 4$ & $146.9^{\mathrm{cd}} \pm 1.31$ & $2.864^{\mathrm{a}} \pm 0.15$ & $41.4^{\mathrm{cd}} \pm 0.67$ & $4.83^{\mathrm{a}} \pm 0.22$ & $13.87^{\mathrm{a}} \pm 0.81$ \\
\hline T5 & $166.3 \mathrm{f} \pm 0.64$ & $4.2^{\mathrm{b}} \pm 0.16$ & $31.3^{\mathrm{a}} \pm 0.6$ & $6.47^{\mathrm{c}} \pm 0.26$ & $42.53^{\mathrm{c}} \pm 4.88$ \\
\hline T6 & $143^{c} \pm 2.08$ & $3.022^{\mathrm{a}} \pm 0.03$ & $43.1^{\mathrm{de}} \pm 0.73$ & $4.73^{\mathrm{a}} \pm 0.26$ & $15.13^{\mathrm{a}} \pm 1.67$ \\
\hline $\mathrm{T} 7$ & $170^{\mathrm{f}} \pm 1.0$ & $4.43^{\mathrm{b}} \pm 0.47$ & $35^{\mathrm{b}} \pm 1.0$ & $7.9^{\mathrm{d}} \pm 0.1$ & $95.9^{\mathrm{d}} \pm 14.9$ \\
\hline $\mathrm{T} 8$ & $149.9^{\mathrm{d}} \pm 0.93$ & $3.055^{\mathrm{a}} \pm 0.27$ & $40.33^{\mathrm{c}} \pm 0.88$ & $5^{\mathrm{a}} \pm 0.1$ & $15.43^{\mathrm{ab}} \pm 2.0$ \\
\hline Grand Mean & 145.66 & 3.22 & 39.76 & 5.378 & 26.096 \\
\hline S.E. & 3.28 & 0.298 & 1.294 & 0.358 & 6.64 \\
\hline LSD & $5.877 * *$ & $0.534 * *$ & $2.318^{* * *}$ & $0.64 * *$ & $11.9 * *$ \\
\hline CV\% & $2.3 \%$ & $9.3 \%$ & $3.3 \%$ & $6.7 \%$ & $25.5 \%$ \\
\hline $\mathrm{p}$ value & $<0.001$ & $<0.001$ & $<0.001$ & $<0.001$ & $<0.001$ \\
\hline
\end{tabular}

Trichoderma with Azotobacter in T4 or with Azotobacter and FYM (T6) highly suppressed the performance of Azotobacter and/or FYM. The increase of plant height, dry shoot weight and 
stem girth in T4 and T6 were $16.4 \%, 43.6 \%, 2.1 \%$ and $13.3 \%, 42.6 \%, 7.9 \%$ respectively. With FYM, the increase of shoot weight was $23.1 \%$ only.

Table 2: Effects of different treatments on different parameters of maize in Lamjung

\begin{tabular}{|c|c|c|c|c|c|}
\hline Treatment & $\begin{array}{l}\text { Leaf number } \\
\text { on } 85 \text { DAS }\end{array}$ & $\begin{array}{l}\text { Leaf length } \\
(\mathrm{cm})\end{array}$ & $\begin{array}{l}\text { Leaf width } \\
(\mathrm{cm})\end{array}$ & $\begin{array}{l}\text { Dry shoot } \\
\text { weight }(\mathrm{g})\end{array}$ & $\begin{array}{l}\text { Dry biomass } \\
\left(\mathrm{t} \mathrm{ha}^{-1}\right)\end{array}$ \\
\hline $\mathrm{T} 1$ & $11.67^{\mathrm{a}} \pm 0.33$ & $39.9^{a} \pm 1.69$ & $5.2^{\mathrm{ab}} \pm 0.1$ & $31.3^{\mathrm{a}} \pm 1.56$ & $0.934^{\mathrm{a}} \pm 0.05$ \\
\hline $\mathrm{T} 2$ & $16.67^{\mathrm{de}} \pm 0.33$ & $56.33^{c} \pm 0.67$ & $4.8^{\mathrm{a}} \pm 0.36$ & $43.93^{\mathrm{a}} \pm 3.64$ & $1.571^{\mathrm{b}} \pm 0.11$ \\
\hline $\mathrm{T} 3$ & $14^{\mathrm{bc}} \pm 1.0$ & $47.37^{\mathrm{b}} \pm 1.48$ & $5.17^{\mathrm{ab}} \pm 0.34$ & $32.83^{\mathrm{a}} \pm 1.72$ & $0.989^{\mathrm{a}} \pm 0.06$ \\
\hline $\mathrm{T} 4$ & $13.33^{\mathrm{ab}} \pm 0.88$ & $62.17^{\mathrm{d}} \pm 1.48$ & $5.33^{\mathrm{ab}} \pm 0.48$ & $44.93^{\mathrm{a}} \pm 1.99$ & $1.307^{\mathrm{ab}} \pm 0.06$ \\
\hline T5 & $15.67^{\mathrm{cd}} \pm 0.33$ & $59.97^{\mathrm{cd}} \pm 1.5$ & $7.43^{c} \pm 0.88$ & $107.87^{\mathrm{b}} \pm 12.54$ & $3.342^{c} \pm 0.39$ \\
\hline T6 & $15.67^{\mathrm{cd}} \pm 0.88$ & $47.53^{\mathrm{b}} \pm 1.3$ & $4.83^{\mathrm{a}} \pm 0.03$ & $44.63^{\mathrm{a}} \pm 3.74$ & $1.328^{\mathrm{ab}} \pm 0.11$ \\
\hline $\mathrm{T} 7$ & $18^{\mathrm{e}} \pm 1.0$ & $79.3^{\mathrm{e}} \pm 1.7$ & $6.4^{\mathrm{bc}} \pm 0.5$ & $115.65^{\mathrm{b}} \pm 4.85$ & $4.701^{\mathrm{d}} \pm 0.44$ \\
\hline $\mathrm{T} 8$ & $13^{\mathrm{ab}} \pm 0.58$ & $62.17^{\mathrm{d}} \pm 1.3$ & $5.6^{\mathrm{ab}} \pm 0.15$ & $38.53^{\mathrm{a}} \pm 3.72$ & $1.199^{\mathrm{ab}} \pm 0.12$ \\
\hline Grand Mean & 14.609 & 55.865 & 5.561 & 54.93 & 1.801 \\
\hline S.E. & 1.193 & 2.388 & 0.741 & 9.28 & 0.324 \\
\hline LSD & $2.137 * *$ & $4.279 * *$ & $1.328 * *$ & $16.63 * *$ & $2.393 * *$ \\
\hline $\mathrm{CV} \%$ & $8.2 \%$ & $4.3 \%$ & $13.3 \%$ & $16.9 \%$ & $18 \%$ \\
\hline $\mathrm{p}$ value & $<0.001$ & $<0.001$ & $<0.001$ & $<0.001$ & $<0.001$ \\
\hline
\end{tabular}

The rapid increase in height in $\mathrm{T} 7$ and $\mathrm{T} 5$ is due to the top dressing of $\mathrm{N}$. $\mathrm{N}$ fertilizer causes increases in plant height in results found by Chandler (1969); Eltelib et al (2006) and Amin (2011) which is associated with the fact that $\mathrm{N}$ promotes plant growth, thus increases the number of internodes, and length of internodes consequently increasing plant height. El-Hoseiny and Rabie (1979) found that bacterization of maize with Azotobacter inclined to stimulate the growth of treated plants as characterized by the increase of root and shoot lengths. It is also observed that plant height and internode length of the corn stalks increased by the use of bacterium Azotobacter which produce cytokinin and its precursors (Nieto \& Frankenberger, 1991). Mirza et al (2000) reported that application of biofertilizers apart from nitrogen fixation, cause the production of auxin that increases lethal fibers and the absorption of nutrients, and consequently improves plant height.

The effects of biological control agent (based on antibiosis, fungistatic and mycoparasitism) Trichoderma is of particular relevance because of the possibility that these antagonists of fungi could also negatively interfere with AMF too. Effects of Trichoderma are difficult to generalize, because of the aggressiveness of the Trichoderma strain used and their survival. Negative efficacy of Trichoderma secondary metabolites is in agreement with Menzies (1993) in cucumber, tomato, and pepper. Hajieghrari (2010) reported the pathogenesis of Trichoderma rather than symbiosis causing necrosis and poor performance. It is reported that the damage of Trichoderma species are species-specific or depend on Trichoderma-maize interaction. Trichoderma with Azotobacter or with Azotobacter and FYM highly suppressed the performance of Azotobacter and/or FYM which might be particularly due to competition among the microorganisms in the rhizosphere or for the reasons unknown. 
Journal of Maize Research and Development (2017) 3 (1):1-16

ISSN: 2467-9291 (Print), 2467-9305 (Online),

DOI: http://dx.doi.org/10.3126/jmrd.v3i1.18915

Addition of nitrogen increases stem girth (John \& Warren, 1967). Pronounced effect on stem girth of maize by Azotobacter application may be due to enough $\mathrm{N}$ fixations. A similar result on stem diameter was reported by Mirza et al. (2000). Trichoderma has inhibiting effects on stem girth, which may be due to an interference of this fungicide to AMF or competitiveness with rhizospheric microorganisms or with available key-nutrients, or out-competing Azotobacter. Although Trichoderma has rarely been regarded as a parasite, there are several reports demonstrating pathogenicity of Trichoderma to maize seed and seedlings (Mc-Fadden and Sutton, 1975; Sutton, 1972), as well as other seeds (Menzies, 1993; Hermosa et al., 2012).

Inorganic fertilizer NPK showed a decrease of $20.5 \%$ and $12.7 \%$ in root length of T5 and T7 respectively over control. The longest root length was seen in Azotobacter (T2) of 12.0\% increase. Trichoderma (T3) displayed an increase of 5.7\% which was 5.0\% when Azotobacter and Trichoderma came together (T4), the antagonistic effect was observed. With FYM (T8), only $2.3 \%$ of the increase was observed which rapidly rose to $9.5 \%$ when FYM combined with Azotobacter and Trichoderma (T6).

Inoculation with biofertilizers causes an increase in root weight. This significant increase in root values may be related to increases in the availability of minerals especially $\mathrm{N}$ due to $\mathrm{N}$ fixation that may lead to an increase photosynthesizing surface. Thus, increase in accumulation of simple sugars and starch in roots occurred and resulted in enhancement of roots. This result is in line with those obtained by El-Gamal (1996) on potato tubers and Sheikh et al (2000) on Duch iris. The decrease in the root-shoot ratio of maize due to Trichoderma inoculation is demonstrated by Hajieghrari (2010).

The highest number of leaves in the maize plant was in treatment T7 (a combination of all sorts of fertilizer) with an increase of 54.2\% respectively over control. Interestingly NPK (T5) treatment showed less number of leaves than Azotobacter (T2) (34.3\% vs 42.8\%). Trichoderma (T3) showed $20.0 \%$ of the increase in leaves while FYM (T8) had only $11.4 \%$ of the increase. Together Azotobacter and Trichoderma (T4) had 14.2\% of the increase in leaves which increased to $34.3 \%$ when also combined with FYM (T6). The highest leaf length was found in T7 (52.8\%) followed by T5 (30.3\%). T8 and T2 showed the negligible increase of $1.3 \%$ and $0.16 \%$ over control while Trichoderma wherever present showed the negative impact. Trichoderma (T3) decreased the leaf length by $5.3 \%$ over control (T1) and T6 by $3.0 \%$, while no change was observed in T4. On the contrary to leaf length, leaf width was highest of all in T5 (NPK only) with an increase of $97.5 \%$ followed by $\mathrm{T} 7$ (73.4\%). There was a decline in width in case of Azotobacter (T2) of $2.2 \%$ over control, while an increase of $14.1 \%$ was observed in Trichoderma treatment (T3). The combination of Azotobacter and Trichoderma in T4 showed a sharp decline of $13.4 \%$ over control, but the leaf width increased highly $(36.5 \%)$ when FYM (T6) was added to it. The increase observed in FYM (T8) was $3.6 \%$ only. 
Journal of Maize Research and Development (2017) 3 (1):1-16

ISSN: 2467-9291 (Print), 2467-9305 (Online), DOI: http://dx.doi.org/10.3126/jmrd.v3i1.18915
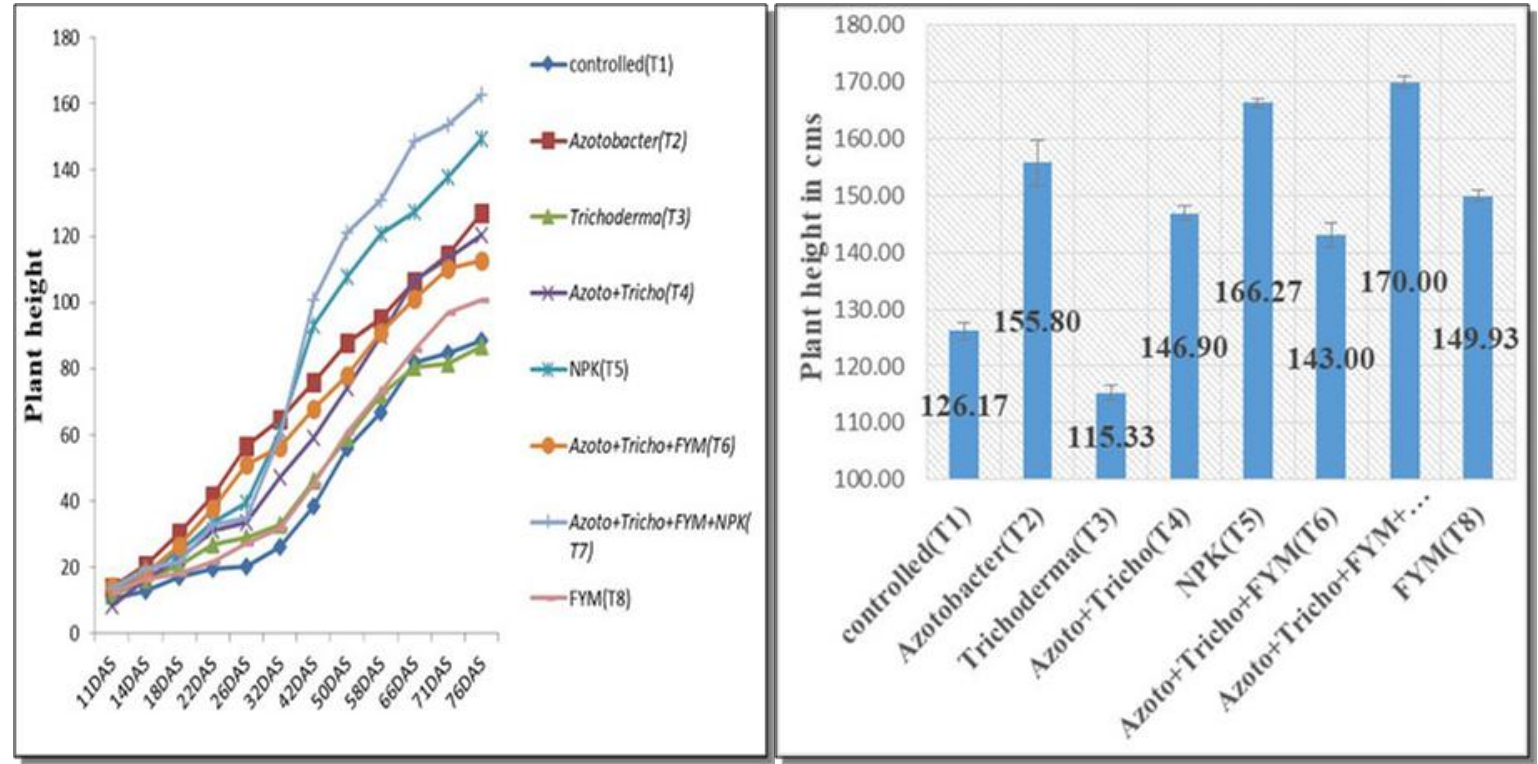

Figure 1: Height of maize plant for a duration

Figure 2: Final height of maize plant

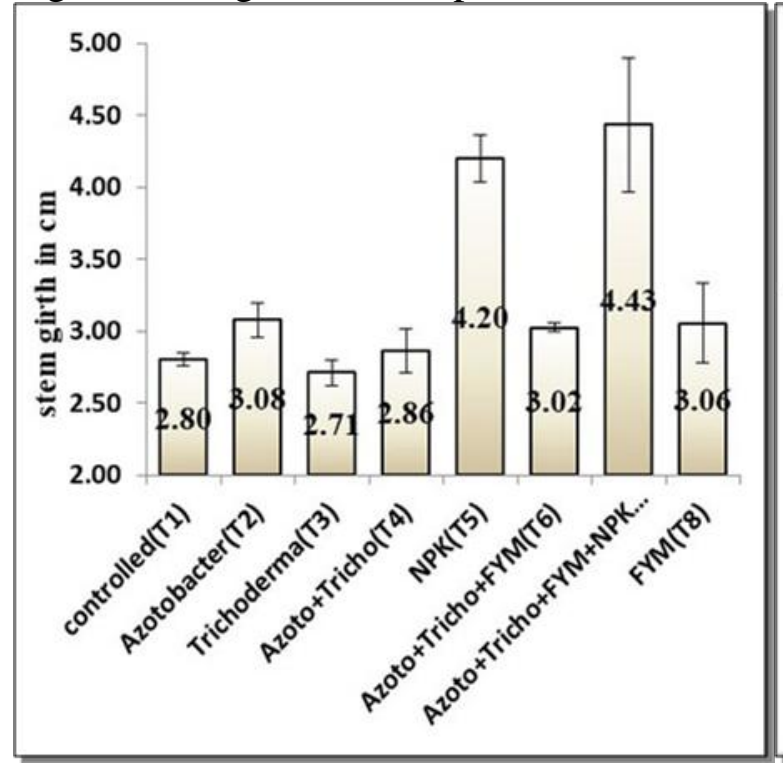

Figure 3: Stem girth of maize plant plant

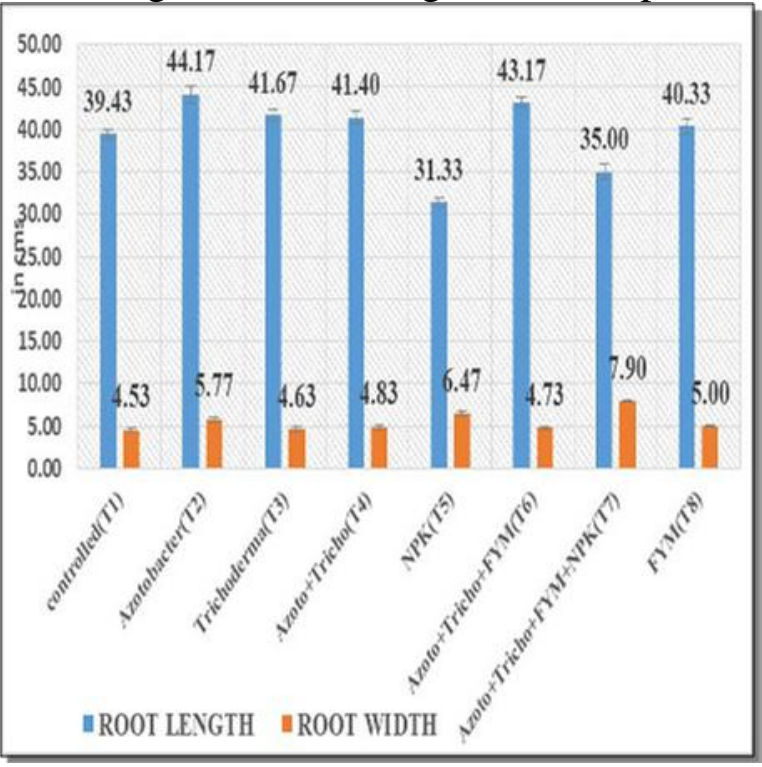

Figure 4: Root length \& width of maize 
Journal of Maize Research and Development (2017) 3 (1):1-16

ISSN: 2467-9291 (Print), 2467-9305 (Online), DOI: http://dx.doi.org/10.3126/jmrd.v3i1.18915

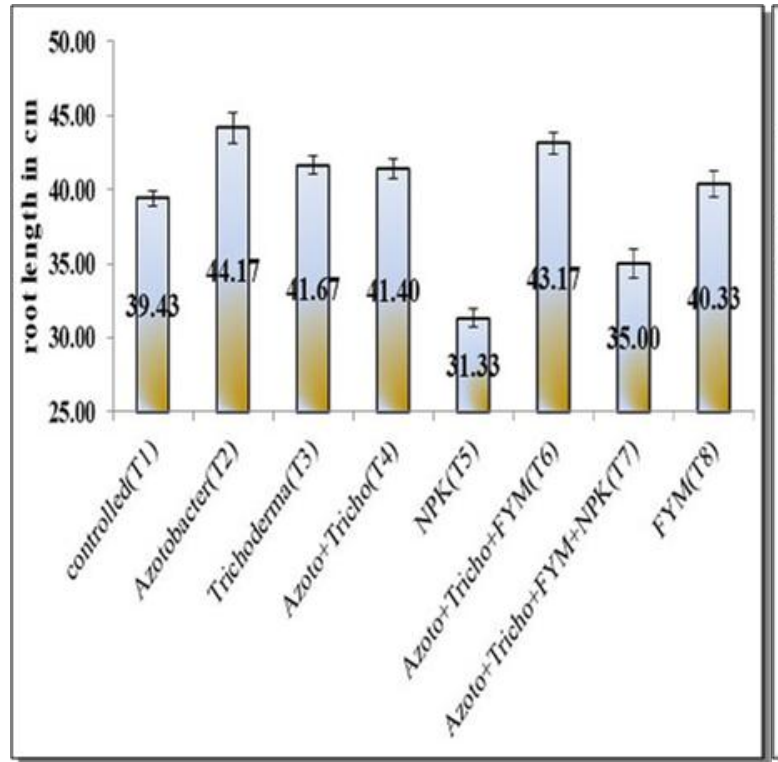

Figure 5: Root length of maize plant

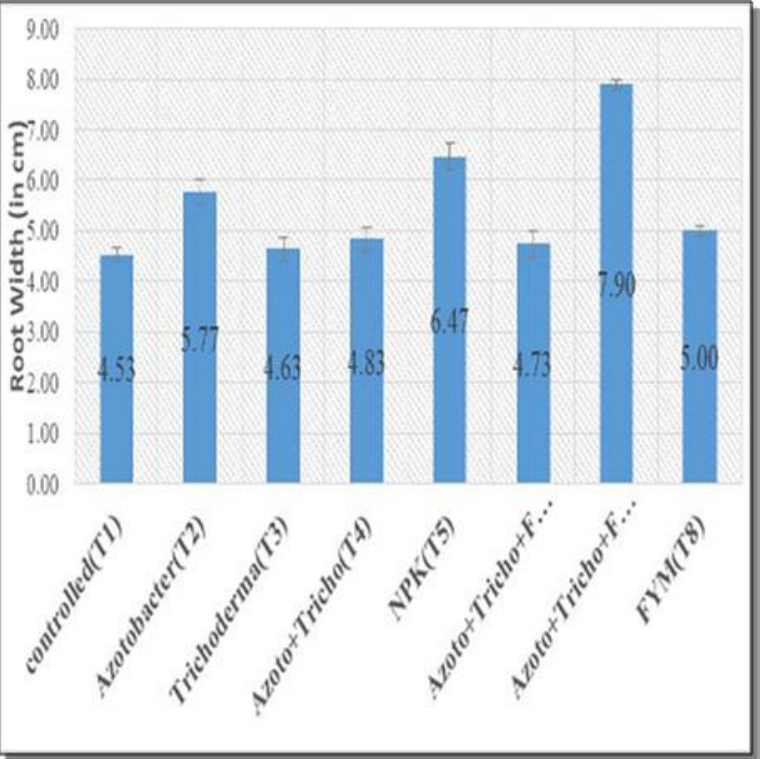

Figure 6: Root width of maize plant

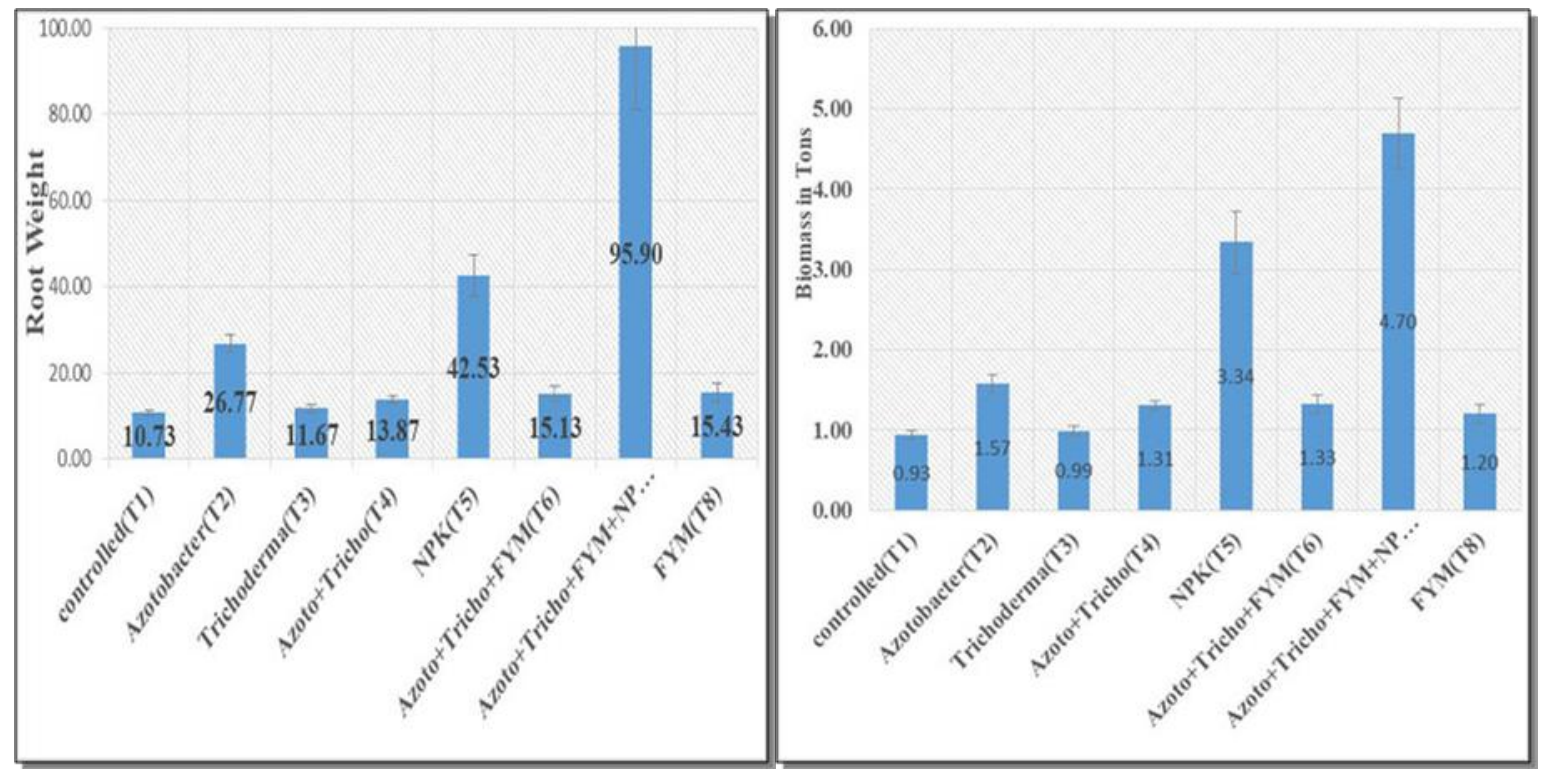

Figure 7: Oven dry root weight of maize after

Figure 8: Total biomass of maize (in ton) harvesting (in $\mathrm{g}$ ) 
Journal of Maize Research and Development (2017) 3 (1):1-16

ISSN: 2467-9291 (Print), 2467-9305 (Online), DOI: http://dx.doi.org/10.3126/jmrd.v3i1.18915

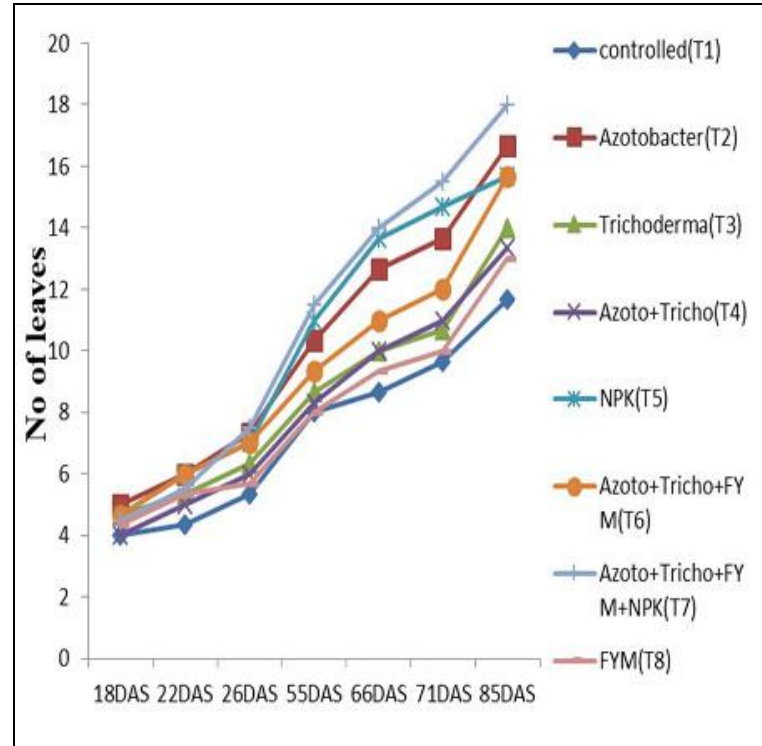

Figure 9: Increment in number of leaves over a duration of maize plant

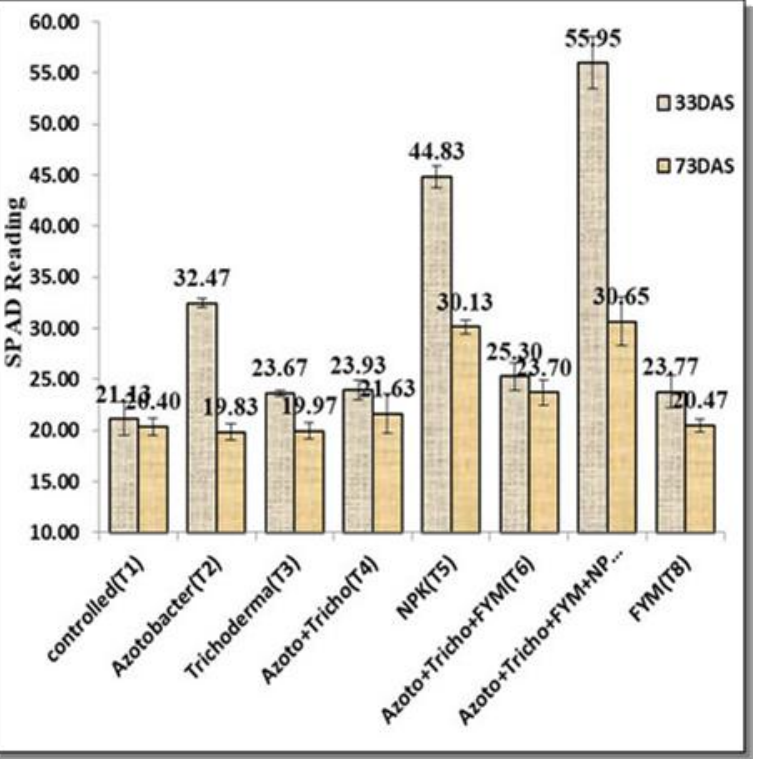

Figure 10: SPAD reading of maize plant on 33 and 73 days after sowing (DAS)

The enhancement in leaves growth as a result of biofertilizers inoculation may be due to the production of phytohormones by the biofertilizers and/or improving the availability of nutrients (Martin et al., 1989; Jagnow et al., 1991).

Table 3: Effects of different treatments on different parameters of maize in Lamjung

\begin{tabular}{|c|c|c|c|c|}
\hline Treatment & $\begin{array}{l}\text { Date of } \\
\text { germination }\end{array}$ & Date of tasseling & $\begin{array}{l}\text { SPAD reading } \\
\text { 33DAS }\end{array}$ & $\begin{array}{l}\text { SPAD reading } \\
\text { 73DAS }\end{array}$ \\
\hline $\mathrm{T} 1$ & $7 \pm 0.0$ & $77^{\mathrm{d}} \pm 1$ & $21.13^{\mathrm{a}} \pm 1.64$ & $20.4^{\mathrm{ab}} \pm 0.84$ \\
\hline $\mathrm{T} 2$ & $7 \pm 0.58$ & $73.33^{b c} \pm 0.88$ & $32.47^{\mathrm{c}} \pm 0.46$ & $19.83^{\mathrm{a}} \pm 0.78$ \\
\hline $\mathrm{T} 3$ & $7.33 \pm 0.33$ & $75^{\mathrm{cd}} \pm 1.15$ & $23.67^{\mathrm{ab}} \pm 0.27$ & $19.97^{\mathrm{a}} \pm 0.75$ \\
\hline $\mathrm{T} 4$ & $7.33 \pm 0.33$ & $75^{\mathrm{cd}} \pm 0.58$ & $23.93^{\mathrm{ab}} \pm 0.96$ & $21.63^{\mathrm{ab}} \pm 1.92$ \\
\hline $\mathrm{T} 5$ & $6.67 \pm 0.33$ & $62.67^{\mathrm{a}} \pm 1.76$ & $44.83^{\mathrm{d}} \pm 1.11$ & $30.13^{c} \pm 0.67$ \\
\hline T6 & $6.67 \pm 0.67$ & $74^{\mathrm{bcd}} \pm 0.58$ & $25.3^{\mathrm{b}} \pm 1.38$ & $23.7^{\mathrm{b}} \pm 1.23$ \\
\hline $\mathrm{T} 7$ & $6.5 \pm 0.5$ & $71^{\mathrm{b}} \pm 0.0$ & $55.95^{\mathrm{e}} \pm 2.55$ & $30.65^{c} \pm 2.35$ \\
\hline $\mathrm{T} 8$ & $6.67 \pm 0.33$ & $83.33^{\mathrm{e}} \pm 0.88$ & $23.77^{\mathrm{ab}} \pm 1.59$ & $20.47^{\mathrm{ab}} \pm 0.6$ \\
\hline Grand Mean & 6.913 & 74.043 & 30.313 & 23.03 \\
\hline S.E. & 0.723 & 1.751 & 2.167 & 1.974 \\
\hline LSD & 1.295 & $3.138 * *$ & $3.883 * *$ & $3.537 * *$ \\
\hline $\mathrm{CV} \%$ & $10.5 \%$ & $2.4 \%$ & $7.1 \%$ & $8.6 \%$ \\
\hline $\mathrm{p}$ value & NS & $<0.001$ & $<0.001$ & $<0.001$ \\
\hline
\end{tabular}


Journal of Maize Research and Development (2017) 3 (1):1-16

ISSN: 2467-9291 (Print), 2467-9305 (Online),

DOI: http://dx.doi.org/10.3126/jmrd.v3i1.18915

Number of leaves seen in T7 and T5 might be due to more availability of nitrogen which is consistent with Okajina et al. (1983); Woldesenbet and Haileyesus (2016). Azotobacter application shows the significant increase in the number of leaves which is in conformity with Barakat and Gabar (1998) in tomato.

Two readings of SPAD were taken on 33 DAS and 73 DAS. In the first reading, T7 showed the highest chlorophyll content increase of $164.8 \%$ over control (T1), which was followed by T5 (112.2\%), and T2 (53.7\%). Trichoderma (T3), farmyard manure (T8) and Trichoderma with Azotobacter (T4) showed a mere increase of 12-13\% chlorophyll content. Chlorophyll content rapidly declined towards maturity, being the highest in T7 again, which was statistically at par with T5, followed by T6. Minimum chlorophyll content was found in T2 and T3 after 73 days. This chlorophyll content is too low for proper growth and development of maize. Highest reading of T7 and T5 on 33 DAS was due to the top dressing of urea. Moving on towards maturity, $\mathrm{N}$ deficiency symptoms were visible, which caused the rapid decline in SPAD reading of maize.

It is well known that nitrogen is present in chlorophyll molecule. Increase in leaf chlorophyll index was recorded by increasing nitrogen rates also mentioned by Kouchebagh et al. (2012). The obtained results for leaf chlorophyll content may be attributed to the micro-organisms effect on nutrients release in soil in available forms leading to the increase of nitrogen content in the plants; this, in turn, led to increasing the chlorophyll content as reported by Moursi et al. (1998) and Larimi et al (2014). Increase in chlorophyll content was observed in maize inoculated with Azotobacter strains which is similar to the findings of Shaukat et al. (2006) in sunflower, ElGamal (1996) in potato plants and Alexandru et al. (2013). Nitrogen-fixing Azotobacter supplies the high amount of nitrogen for tissue growth, thus, increases chlorophyll content (Shanthi et al., 2012).

Days to tasseling was minimum in NPK treatment (T5). The increasing order of tasseling days and treatments were T5 (62.7 days) < T7 (71 days) < T2 (73.3 days) < T6 (74 days) < T3 (75 days $)=\mathrm{T} 4$ (75 days) $<\mathrm{T} 1$ (77 days $)<\mathrm{T} 8$ (83.3 days). The only positive impact of the association of Azotobacter and Trichoderma was observed in biomass with an increase of $149.8 \%$ over control (T1) while Azotobacter (T2) had a biomass increase of $68.2 \%$ and Trichoderma (T3) had an increase of 5.9\%. The highest of biomass increase of $403.3 \%$ was observed in T7 (Azotobacter + Trichoderma + FYM + NPK) followed by $257.8 \%$ in T5 (NPK only). The increase of biomass in T8 (FYM only) was $28.4 \%$ while in T6 (Azotobacter + Trichoderma + FYM), it was found to be $42.2 \%$. Although application of urea to maize has increased its dry matter significantly, Azotobacter has also significant effects on corn dry matter yield. High dry matter in those treatments is due to long plant height, high stem girth, and high root weights. Fresh biomass yield is higher in high $\mathrm{N}$ supplement which is in harmony with Amin (2011). Nitrogen fertilization results in increased maize biomass up to $25-42 \%$ in results found by Ogola et al (2002).

Trichoderma shows delayed germination compared to Azotobacter. Trichoderma when used with Azotobacter inhibit the response of Azotobacter and delays the germination. Whether inorganic fertilizers NPK or FYM combined Azotobacter \& Trichoderma or FYM itself show faster germination. The fastest germination is observed when biofertilizer, FYM, and inorganic fertilizer are mixed. As far as parameters like plant height, stem girth, dry shoot weight, root 
Journal of Maize Research and Development (2017) 3 (1):1-16

ISSN: 2467-9291 (Print), 2467-9305 (Online),

DOI: http://dx.doi.org/10.3126/jmrd.v3i1.18915

length and width, and root weight are concerned Azotobacter shows a positive increase in all these parameters while Trichoderma displays either negative or minimal impact comparative to Azotobacter. Impact of farmyard manure is lower than Azotobacter but appreciably higher than Trichoderma. Trichoderma greatly inhibits the expression of Azotobacter when used together. Trichoderma even suppresses the outcome (except shoot weight) of farmyard manure when used in a combination of Azotobacter, Trichoderma, and FYM. Though all these parameters are the highest (except root length) in NPK when combined with Azotobacter, Trichoderma, and FYM, the result is comparable with NPK when used alone. Azotobacter or Trichoderma or FYM increases root length and number of leaves. Trichoderma wherever present showed the negative impact on leaf length, unlike Azotobacter. Minimum chlorophyll content is seen in biofertilizer treatment towards maturity. Days to tasseling is comparatively lower for Azotobacter than Trichoderma while it is minimum in NPK treatment. The only positive impact of the association of Azotobacter and Trichoderma is observed in biomass increase. While Trichoderma merely increases the biomass, Azotobacter highly increases total biomass. The highest of biomass increase was in the combination of Azotobacter, Trichoderma, FYM, and NPK. Although the application of urea to maize increased its dry matter significantly, Azotobacter had also significant effects on corn dry matter yield. High dry matter in those treatments is due to long plant height, high stem girth, and high root weights.

\section{CONCLUSION}

Azotobacter spp. showed the positive impact on growth parameters while Trichoderma viride inhibits the growth parameters. When combined together, inhibitory nature of Trichoderma overlaps or antagonizes the effect of Azotobacter in maize plant. So the study indicates that use of Trichoderma with seeds may not be a wise choice from growth point of view.

\section{ACKNOWLEDGEMENTS}

This research received no specific grant from any funding agency in the public, commercial, or not-for-profit sectors. The authors are thankful to AASRA Research and Education Academic Counsel for providing the strains like Azotobacter spp. and Trichoderma viride and other technical support.

\section{AUTHOR CONTRIBUTIONS}

S.M. conceived and designed the experiments, analyzed the data and wrote the paper, and revised the article for the final approval of the version to be published. S.N. collected the data, analyzed the data and wrote the paper.

\section{CONFLICTS OF INTEREST}

The authors declare that there is no conflict of interest. 
Journal of Maize Research and Development (2017) 3 (1):1-16

ISSN: 2467-9291 (Print), 2467-9305 (Online),

DOI: http://dx.doi.org/10.3126/jmrd.v3i1.18915

\section{REFERENCES}

Akladious, S. A., \& Abbas, Md. S. (2014). Application of Trichoderma harzianum T22 as a biofertilizer supporting maize growth. African Journal of Biotechnology, 11(35), 86728683. http://doi.org/10.5897/AJB11.4323

Alexandru, M., Lazăr, D., Ene, M., \& Şesan, T. E. (2013). Influence of some Trichoderma species on photosynthesis intensity and pigments in tomatoes. Romanian Biotechnological Letters, 18(4), 8499-8510.

Amin, M. E. H. (2011). Effect of different nitrogen sources on growth, yield, and quality of fodder maize (Zea mays L.). Journal of the Saudi Society of Agricultural Sciences, 10(1), 17-23. https://doi.org/10.1016/j.jssas.2010.06.003.

Amiri, A. \& Rafiee, M. (2013). Effect of soil inoculation with Azospirillum and Azotobacter bacteria on nitrogen use efficiency and agronomic characteristics of corn. Annals of Biological Research, 4 (2), 77-79.

Bákonyi, N., Bott, S., Gajdos, É., Szabó, A., Jakab, A., Tóth, B., Makleit, P., \& Veres, S. Z. (2013). Using biofertilizer to improve seed germination and early development of maize. Pol. J. Environ. Stud., 22, 1595-1599.

Barakat, M. A. S. \& Gabar, S. M. (1998). Effect of different biofertilizer types and nitrogen fertilizer levels on tomato plants. Alexandria. Journal of Agricultural Research, 43(1), 149-160.

Beyranvand, H., Farnia, A., Nakhjavan, S.H., \& Shaban, M. (2013). The response of yield and yield components of maize (Zea mays L.) to different biofertilizers. International journal of Advanced Biological and Biomedical Research, 1(9), 1068-1077.

Chandler, R. F. Jr. (1969). Plant morphology and stand geometry in relation to nitrogen. In J. D. Eastin, F. A. Haskins, C. Y. Sullivan, \& C. H. M. Van Bavel (Eds.), Physiological Aspects of Crop Yield,(pp. 265-85). Madison, Wis: Am. Soc. Agron.

Druzhinina, I. S., Kopchinskiy, A. G., \& Kubicek, C. P. (2006). The first 100 Trichoderma species characterized by molecular data. Mycoscience, 47, 55-64. https://doi.org/10.1007/s10267-006-0279-7

El-Gamal, A. M. (1996). The response of potato in newly reclaimed areas to mineral nitrogen fertilizer levels and nitrogen-fixing biofertilizer Halex 2. Assiut Journal of Agricultural Sciences, 27, 89-99.

El-Hoseiny, M. M. \& Rabie, M. R. (1979). Effect of bacterization of maize seedings with Azotobacter chroococcum on their growth. Egypt J. Microbiol., 14 (1-2), 45-57.

Eltelib, H. A., Hamad, M. A., \& Ali, E. E. (2006). The effect of nitrogen and phosphorus fertilization on growth, yield, and quality of forage maize (Zea mays L.). Journal of Agronomy, 5(3), 515-518.

Farnia, A., \& Ashjardi, V. (2015). Effect of nitrogen biofertilizers on yield and yield components of different maize (Zea mays L.) Cultivars. International Journal of Life Sciences, 9(5), 117-121. http://dx.doi.org/10.3126/ijls.v9i5.12711

Hajieghrari, B. (2010). Effects of some Iranian Trichoderma isolates on maize seed germination and seedling vigor. African Journal of Biotechnology. 9(28), 4342-4347. 
Journal of Maize Research and Development (2017) 3 (1):1-16

ISSN: 2467-9291 (Print), 2467-9305 (Online),

DOI: http://dx.doi.org/10.3126/jmrd.v3i1.18915

Harman, G.E., Petzoldt, R., Comis, A., \& Chen, J. (2004). Interactions between Trichoderma harzianum strain T22 and maize inbred line Mo17 and effects of these interactions on diseases caused by Pythium ultimum and Colletotrichum graminicola. Phytopathology. 94(2), 147-53.

Hermosa, R., Viterbo, A., Chet, I., \& Monte, E. (2012). Plant-beneficial effects of Trichoderma and of its genes. Microbiology, 158, 17-25.

HLPE, 2013. Biofuels and food security. A report by the High-Level Panel of Experts on Food Security and Nutrition of the Committee on World Food Security, Rome.

Hoyos-Carvajal, L., Orduz, S., \& Bissett, J. (2009). Growth stimulation in bean (Phaseolus vulgaris L.) by Trichoderma. Biological Control, 51(3), 409-416, https://doi.org/10.1016/j.biocontrol.2009.07.018.

Jagnow, G., Hoflick, G., \& Hoffmann, K. H. (1991). Inoculation of non-symbiotic rhizosphere bacteria: Possibilities of increasing and stabilizing yields. Agnew Botanik, 65, 97-126.

John, H.M. \& Warren, H.L. (1967). Pasture and pasturage. In: Principle of Field Crop Production, pp. 257-258.

Kaewchai, S., Soytong, K., \& Hyde, K. D. (2009). Mycofungicides and fungal biofertilizers. Fungal Diversity, 38, 25- 50.

KC, G., Karki, T. B., Shrestha, J., \& Achhami, B. B. (2015). Status and prospects of maize research in Nepal. Journal of Maize Research and Development, 1(1), 1-9. https://doi.org/10.3126/jmrd.v1i1.14239

Kleifeld, O., \& Chet, I. (1992). Trichoderma harzianum - interaction with plants and effect on growth response. Plant and Soil, 144(2), 267-272.

Köhl, J., \& Schlösser, E. (1989). The decay of sclerotia of Botrytis cinerea by Trichoderma sp. at low temperatures, J. Phytopathol., 125: 320.http://doi.org/10.1111/j.14390434.1989.tb01076.x

Kouchebagh, S. B., Mirshekari, B., \& Farahvash, F. (2012). Improvement of corn yield by seed biofertilization and urea application. World Applied Sciences Journal. 16(9), 1239-1242.

Larimi, S. B., Shakiba, M., Mohammadinasab, A. D., \& Vahed, M. M. (2014). Changes in nitrogen and chlorophyll density and leaf area of Sweet Basil (Ocimum basilicum L.) affected by biofertilizer and nitrogen application. International Journal of Biosciences, 5(9), 256-265.

Laxminarayana, K. (2001). Effect of Azotobacter and Azospirillum on yield performance of maize in hilly regions of Mizoram. Indian Journal of Hill Farming, 14 (2), 134-137.

Martin, P., Galatzle, A., Klob, W., Omay, H. \& Schmdidt, W. (1989). Nitrogen-fixing bacteria in the rhizosphere quantification and hormonal effects on root development. Z. Pflanzernahr Bodenk., 152, 237-245.

McFadden, A.G., \& Sutton, J.C. (1975). Relationship of populations of Trichoderma spp. in the soil to disease in maize. Canadian Journal of Plant Science, 55, 579586. https://doi.org/10.4141/cjps75-085 
Journal of Maize Research and Development (2017) 3 (1):1-16

ISSN: 2467-9291 (Print), 2467-9305 (Online),

DOI: http://dx.doi.org/10.3126/jmrd.v3i1.18915

Menzies, J. G. (1993). A strain of Trichoderma viride pathogenic to germinating seedlings of cucumber, pepper, and tomato. Plant Pathol. 42, 784-791.https://doi.org/10.1111/j.13653059.1993.tb01565.

Mirza, M. S., Rasul, G., Mehnaz, S., Ladha, J. K., So, R. B., Ali S., \& Malik, K. A. (2000). Beneficial effects of nitrogen-fixing bacteria on rice. In J. K. Ladha \& P. M. Reddy (Eds.), The Quest for Nitrogen Fixation in Rice (pp. 191-204). Los Baños: IRRI.

Molla, A. H., Haque, Md. M., Haque, Md. A., \& Ilias, G.N.M. (2012). Trichoderma-enriched biofertilizer enhances production and nutritional quality of tomato (Lycopersicon esculentum Mill.) and minimizes NPK fertilizer use. Agricultural Research, 1(3), 265272. https://doi.org/10.1007/s40003-012-0025-7

Moreno, J., Lopez, J. G., Vela, G.R. (1986). Survival of Azotobacter spp. in dry soils. App Env Microb, 51(1), 123-125.

Moursi, M. A., Nour El-Din, N. A., El-Bagoury, O. H., Saad, A. O. M., \& Ashour, N. I. (1998). Photosynthetic apparatus of maize plants as influenced by spraying with urea. In: Garab G. (Eds) Photosynthesis: Mechanisms and Effects. Springer, Dordrecht https://doi.org/10.1007/978-94-011-3953-3_903

Nieto, K. F. \& Frankenberger Jr, W. T. (1991). Influence of adenine, isopentyl alcohol and Azotobacter chroococcum on vegetative growth of Zea mays. Plant and Soil, 135, 213221. https://doi.org/10.1007/BF00010909

Ogola, J. B. O., Wheeler, T. R., \& Harris, P. M. (2002). Effects of nitrogen and irrigation on water use of maize crops. Field Crop Research, 78(2-3), 105-117. https://doi.org/10.1016/S0378-4290(02)00116-8

Okajina, H., Taniyama, I., Kawakami, R., \& Fujitsu, I., (1983). The nitrogen balance in the soils growing corn. J. Facul. Agr. Hokkaido Univ. 61, 323-343.

Okoroafor, I. B., Okelola, E. O., Edeh, O. N., emehute, V. C., Onu, C. N., Nwaneri, T. C., \& Chinaka G. I. (2013). Effect of organic manure on the growth and yield performance of maize in Ishiagu, Ebonyi State, Nigeria. Journal of Agriculture and Veterinary Science, 5(4), $28-31$.

Olaniyan, A. B., Akintoye, H. A., \& Balogun, M. A. (2004). Effect of different sources and rates of nitrogen fertilizer on growth and yield of sweet corn.<http://www.tropentag.de/2004/abstracts/full/146.pdf> [accessed 1201 2017]

Saravanakumar, K., Li, Y., Yu, C., Wang, Q., Wang, M., Sun, J., Gao, J., \& Chen, J. (2017). Effect of Trichoderma harzianum on maize rhizosphere microbiome and biocontrol of Fusarium Stalk rot. Scientific Reports, 7, 1771p. http://doi.org/10.1038/s41598-01701680-w

Shanthi, J., Santhi, V., Ramya, S., \& Balagurunathan, R. (2012). Effect of Azotobacter spp. and phosphobacter bioinoculants on the growth of sunflower (Helianthus annuus L.). World Journal of Agricultural Research Sciences, 8(2), 218-222. 
Journal of Maize Research and Development (2017) 3 (1):1-16

ISSN: 2467-9291 (Print), 2467-9305 (Online),

DOI: http://dx.doi.org/10.3126/jmrd.v3i1.18915

Shaukat, K., Afrasayab, S., \& Hasnain, S. (2006). Growth responses of Helianthus annuus to plant growth promoting rhizobacteria used as biofertilizers. International Journal of Agricultural Research, 1(6), 573-581.https://doi.org/10.3923/ijar.2006.573.581

Sheikh, M. Q., Jhon, A. Q., \& Zargar, M. Y. (2000). Effect of nitrogen fertilizer and biofertilizers on vegetative growth and bulb production characteristics of Dutch iris (Iris hollandica) cv." Prof. Blaauw". Applied biological Research, 2(1/2), 62-63.

Soliman, S., \& Abel Monem, M. (1994). Influence of 15N labeled urea and Azotobacter on corn yield and nitrogen budget as affected by organic matter. Proceeding of the 2nd Arab Conference on the Peaceful Uses of Atomic Energy. 5-9 November, Cairo pp. 683-694.

Sutton, J. (1972). Trichoderma koningii as a parasite of maize seedlings. Canadian Journal of Plant Science, 52, 1037-1042.

Timsina, K. P., Ghimire, Y. N., \& Lamichhane, J. (2016). Maize production in mid hills of Nepal: from food to feed security. Journal of Maize Research and Development, 2(1), 2029.http://dx.doi.org/10.3126/jmrd.v2i1.16212

Wani, S. A., Chand, S., Wani, M. A., Ramzan, M., \& Hakeem, K. R. (2016). Azotobacter chroococcum - A Potential Biofertilizer in Agriculture: An Overview. In K. Hakeem, J. Akhtar, \& M. Sabir (Eds.), Soil science: Agricultural and environmental prospectives (pp. 333-348). Springer, Cham. https://doi.org/10.1007/978-3-319-34451-5_15

Woldesenbet, M. \& Haileyesus, A. (2016). Effect of nitrogen fertilizer on growth, yield and yield components of maize (Zea mays L.) in Decha district, Southwestern Ethiopia. International Journal of Research - Granthaalayah, 4(2), 95-100.

Yedidia, I., Benhamou, N., \& Chet, I. (1999). Induction of defense responses in cucumber plants (Cucumis sativus L.) by the biocontrol agent Trichoderma harzianum. Applied and Environmental Microbiology, 65(3), 1061-70. 